\title{
Polyvalvular heart disease syndrome
}

INSERM

\section{Source}

INSERM. (1999). Orphanet: an online rare disease and orphan drug data base.

Polyvalvular heart disease syndrome. ORPHA:228410

Polyvalvular heart disease syndrome is a recently described syndrome characterized by the combination of polyvalvular heart disease, short stature, facial anomalies and intellectual deficit. 